\title{
Phytotherapy as a Complementary Medicine for Multiple Sclerosis
}

\author{
Multipl Sklerozda Tamamlayıcı Tedavi Olarak Fitoterapi
}

\author{
(D) Zahra RABIEI* \\ Shahrekord University of Medical Sciences, Basic Health Sciences Institute, Medical Plants Research Center, Shahrekord, Iran
}

\begin{abstract}
Multiple sclerosis (MS) is the most common cause of neurologic disability in adults worldwide. Two main issues have caused MS patients to face several problems. One issue is that the definite cause of MS has not yet been determined and the other issue is the lack of a definite treatment for this disease. The people with MS, therefore, seek out complementary and alternative medications to manage the symptoms of this disease. Meanwhile, medicinal plants have been demonstrated to have possible positive pharmacological effects in treating MS in different models. The reliable articles indexed in the databases Web of Science, Scopus, PubMed Central, PubMed, Scientific Information Database, and Institute for Scientific Information were retrieved and analyzed to conduct this review. Medicinal plants and plant compounds caused decreases in the neurologic deficits due to MS. Clinical evidence has demonstrated the clinical potential of Cannabis sativa extract, cannabinoids, Ginkgo biloba, beta-phytosterol, and Lippia citriodora extract to improve MS symptoms. These plants and compounds can also improve spasticity, muscle spasm, neuropathic pain, and urinary tract complications in at least some of these patients. Nanocurcumins and Punica granatum L. peel extract have exhibited positive effects in animal models and can decrease neurologic deficits by reducing inflammation. Medicinal plants and their compounds can serve as new sources of MS drugs because they can improve MS symptoms.
\end{abstract}

Key words: Multiple sclerosis, phytotherapy, medicinal plants

öz

Multipl skleroz (MS), dünya çapında yetişkinlerde en sık görülen nörolojik problemdir. MS hastalarının pek çok sorunla karşı karşıya kalmasına neden olan iki ana sorun bulunmaktadır. İlk sorun, MS'in kesin nedeninin henüz belirlenmemiş olmasıdır. Diğer problem ise bu hastalık için kesin bir tedavinin olmayışıdır. Bu nedenle, MS'li hastalar, bu hastalığın semptomlarını giderebilmek için tamamlayıcı ve alternatif tedavi arayışındadırlar. Aynı zamanda, tıbbi bitkilerin, MS'in farklı modellerde tedavisinde olası olumlu farmakolojik etkilere sahip olduğu gösterilmiștir. Bu derlemenin hazırlanmasında, Web of Science, Scopus, PubMed Central, PubMed, Scientific Information Database ve Institute for Scientific Information gibi veri tabanlarında indekslenen güvenilir makalelere bașvurulmuş ve değerlendirilmiștir. Tıbbi bitkiler ve bitkisel bileșikler, MS kaynaklı nörolojik problemlerin azalmasını sağlamıştır. Klinik çalışmalar, MS semptomlarını iyileștirmek için Cannabis sativa ekstresi, kannabinoidler, Ginkgo biloba, beta-fitosterol ve Lippia citriodora ekstresinin klinik potansiyelini ortaya koymuştur. Bu bitkiler ve bileşikler, bu hastaların en azından bazılarında spastisite, kas spazmı, nöropatik ağrı ve idrar yolu komplikasyonlarını iyileștirebilmektedir. Nanokurkuminler ve Punica granatum L. kabuğu ekstresi, hayvan modelleri üzerinde olumlu etkiler göstermiş ve inflamasyonu azaltarak nörolojik bozuklukları azaltmıştır. Tıbbi bitkiler ve bunların bileşikleri, MS semptomlarını iyileștirebildikleri için yeni MS ilaç kaynakları olarak kullanılabilir.

Anahtar kelimeler: Multipl skleroz, fitoterapi, tıbbi bitkiler

\section{INTRODUCTION}

Multiple sclerosis (MS) is an inflammatory, central nervous system (CNS)-demyelinating disease that is characterized by autoimmune presentations. In MS, the immune system is stimulated for unknown reasons and specific lymphocytes against myelin are activated. The entry of these cells into the brain plays a role in the immunopathology of MS and the exacerbation of the inflammatory responses in the brain. MS is 2-3 times more prevalent in women than in men and often occurs in the age range of 20 to 40 years. 'The most important symptoms of MS include motor paralysis, sensory degeneration, visual impairment, and cognitive impairment. No definite treatment for MS has yet been offered and certain drugs are available only to improve disease symptoms and slow down its progression. $^{2}$

Although people with MS have life spans similar to those of others, they experience major changes due to changes in the quality of their lives. ${ }^{3}$ The treatments of choice for MS include conventional treatments such as beta-interferon and complementary and alternative therapies. Alternative therapies 
are increasingly being welcome day by day such that one out of every three people is projected to use these treatments during his/her lifespan for common diseases such as back pain, headache, anxiety, and depression. ${ }^{4}$ The use of complementary and alternative medicine to treat chronic diseases such as Parkinson disease, epilepsy, and cancer has raised the potential of these therapies to treat MS. Although the conventional treatment for MS can help to decrease the frequencies of relapses and the severity of the disease and also slow down its progression, ${ }^{5}$ it is only partly effective to treat symptoms and improve functioning and quality of life. Patients, therefore, often seek out various other ways to treat MS.

Alternative medicine or complementary medicine refers to different approaches to treat or prevent diseases whose protocols or efficacies are different from those of conventional or biological approaches. These approaches include exercise, meditation, medical nutrition therapy and phytotherapy, energy therapy and relaxation, acupuncture, and pressure medicine. ${ }^{6}$

Recent studies have shown promising results regarding the effects of medicinal plants to treat or prevent different diseases including Alzheimer disease, ${ }^{7,8}$ stroke, $^{9,10}$ depression, ${ }^{11,12}$ and drug abuse..$^{13}$

In the study by Giveon et al. ${ }^{14}$ with 150 physicians, 68\% of the physicians reported that $15 \%$ of their patients used complementary medicine and $40 \%$ conjectured that $10 \%$ of patients used medicinal plants in treating diseases.

\section{Pathogenesis of MS}

In MS, acute inflammation, which is accompanied by demyelination, acts as a strong stimulus to mobilize the oligodendrocyte precursor cells. Suppressing inflammatory responses can lead to defective repair. Perhaps one reason for the impairment of remyelination in patients is that they are treated with anti-inflammatory drugs such as corticosteroids. When inflammation is suppressed, remyelination remains incomplete and demyelination becomes chronic.

The etiology of MS is still unknown and it is argued that a combination of genetics and environmental factors may lead to the onset of MS. Genetically, MS is most associated with the human leukocyte antigen located on chromosome $6 .^{15}$

MS is an autoimmune disease of the CNS. The most important protein components of the myelin that target the immune system include myelin basic protein, myelin-associated glycoprotein, protein proteolipid protein, and myelin oligodendrocyte glycoprotein. ${ }^{16}$

The roles of different components of the immune system in the occurrence of MS have been studied. The resident microglia and macrophages of the CNS are involved in exerting phagocytotic activities, donating antigen, and producing cytokines. The macrophages and microglia contribute to demyelinating nerves and phagocytosing myelin by producing inflammatory cytokines and myeloperoxidase. ${ }^{17}$

The number of mast cells in the CNS is low in normal conditions but increases in the platelets and inflammatory lesions in MS. Regulated on activation, normal T cell expressed and secreted is a potential absorbent of the mast cells that increases in the cerebrospinal fluid (CSF) of MS patients. Mast cell proteases such as tryptase and chymase activate matrix metalloproteinases (MMPs) and mast cells can produce MMP9 and MMP2. The MMPs can contribute to degenerating tissues such as the blood-brain barrier (BBB). ${ }^{16}$

The number of dendritic cells that act as antigen-donating cells is very low in the CNS in normal conditions but increases in the peripheral blood and CSF in patients with MS. ${ }^{17}$

Certain subgroups of natural killer (NK) cells contribute to regulating the immune system in MS. It has been reported that NK cells in patients with relapse-remitting MS express greater amounts of Fas (CD95) and also secrete the cytokines of $T$ helper 2 (Th2) cells such as interleukin 5 (IL-5) and IL-13. In the immune system, the Th cells are classified into different subgroups depending on the pattern of the produced cytokines, including Th2, Th1, Th17, Th9, and Th22. The other subgroup of T cells, known as regulatory $T$ cells (Tregs), are also essential to maintain self-tolerance. ${ }^{18}$

Th1 lymphocytes produce certain cytokines such as IL-2 tumor necrosis factor (TNF)- $\alpha, T N F-\delta$, and granulocyte-macrophage colony-stimulating factor (GM-CSF) and play important roles in increasing delayed sensitivity and defense against intracellular pathogens. The differentiation of Th1 cells from naïve $T$ cells depends on interferon (IFN) and IL-12 that express the T-bet factor, which is indeed the specific patterning factor of Th1 cells, by activating the signal transducers STAT-1 and then STAT-4. The T-bet factor leads to production of Th1 cytokines, especially IFN- $\delta$, and therefore strengthens the differentiation of Th cells via developing a positive feedback ring. Meanwhile, the T-bet factor also leads to suppression of differentiation of other Th cell subgroups. IFN- $\delta$ is the most important cytokine of Th1 cells and leads to an increase in toll-like receptor expression, induction of immunoglobulin production, increase in phagocytosis, major histocompatibility complex classes I and || molecules, and alienation as well as activation of macrophages. ${ }^{19}$

Th17 cells produce a variety of cytokines, such as IL-17a, IL17F, IL-6, IL-9, IL-21, IL-22, IL-23, TNF- $\alpha$, GM-CSF, and IL-26. However, IL-17A is a specific cytokine of these cells. In humans, the effects of IL-17 in demyelinating nerve cells in MS patients have been demonstrated, and MS exacerbation is associated with an increase in the number of Th17 cells in the patients' blood. During the development of experimental autoimmune encephalomyelitis (EAE), Th17 cell infiltration occurs in the brain before the onset of clinical symptoms, while a significant Th1 cell infiltration occurs after the development of EAE. ${ }^{20}$ The purpose of this article is to review the findings of the studies with animal models as well as clinical trials on the effects of medicinal plants and their compounds on MS (Table 1).

\section{DISCUSSION}

The use of medicinal plants has long been on the rise and the evidence indicates that this trend will predictably persist. The use of medicinal plants is more common in patients at risk 
Table 1. Medicinal herbs and plant compounds affecting MS

\begin{tabular}{llll}
$\begin{array}{l}\text { The name of plant } \\
\text { or compound }\end{array}$ & Concentration & Study design and subjects & Properties \\
\hline Cannabis sativa & $\begin{array}{l}\text { Oral use of Cannabis } \\
\text { sativa extract 5-25 mg } \\
\text { daily for } 10 \text { weeks }\end{array}$ & $\begin{array}{l}\text { Double-blind, placebo- } \\
\text { controlled clinical trial }\end{array}$ & $\begin{array}{l}\text { Relaxation of stiff muscles after 4, 8, and 12 weeks of } \\
\text { treatment compared to the placebo group }\end{array}$ \\
\hline $\begin{array}{l}\text { Delta-9 THC and } \\
\text { CBD }\end{array}$ & $\begin{array}{l}\text { Oral use of THC with } \\
\text { CBD spray at } 2.5 \mathrm{mg} /\end{array}$ & $\begin{array}{l}\text { Clinical trial } \\
\text { Open-label pilot study }\end{array}$ & $\begin{array}{l}\text { Reducing urinary urgency, urination frequency and urine } \\
\text { volume, urinary incontinence and night time urination } \\
\text { frequency after treatment; Decreasing daily total body } \\
\text { weight, reducing catheterization and urinary incontinence; } \\
\text { Reelieving pain and improving muscle stiffness and the } \\
\text { quality of sleep }\end{array}$ \\
\hline
\end{tabular}

\begin{tabular}{|c|c|c|c|c|}
\hline Cannabis sativa & $\begin{array}{l}\text { Aerial parts, ethanol } \\
\text { extract, intraperitoneal } \\
\text { administration of } \\
\Delta \text { THC-rich9 extract at } \\
50 \mathrm{mg} / \mathrm{kg} \text { and CBD-rich } \\
\text { extract at } 50 \mathrm{mg} / \mathrm{kg}\end{array}$ & $\begin{array}{l}\text { Experimental study } \\
\text { with mouse model } \\
\text { of autoimmune } \\
\text { encephalomyelitis } \\
\text { (acute and chronic } \\
\text { phase) }\end{array}$ & $\begin{array}{l}\text { Reducing neurologic deficits after administration with } \\
\triangle \mathrm{THC} \text {-rich9 extract }\end{array}$ & 23 \\
\hline
\end{tabular}

blind, randomized

$\begin{array}{lll}\text { Cannabis sativa } & \text { Capsule containing } 2.5 & \begin{array}{l}\text { blind, randomized } \\ \text { design placebo }\end{array} \text { Improving spasm frequency, movement }\end{array}$ $\mathrm{mg}$ THC and $0.9 \mathrm{mg} \quad$ controlled crossover; 57 patients, administration for 14 days

\begin{tabular}{|c|c|c|c|c|}
\hline Sativex & $\begin{array}{l}\text { Sativex used as } \\
\text { inhaled containing } 2.7 \\
\mathrm{mg} \mathrm{THC} \text { and } 2.5 \mathrm{mg} \\
\text { CBD/spray puff }\end{array}$ & $\begin{array}{l}\text { Double-blind, placebo- } \\
\text { controlled clinical trial }\end{array}$ & $\begin{array}{l}160 \text { patients } \\
\text { Decreasing muscle spasm }\end{array}$ & 25 \\
\hline$\beta$-SIT & $1,4,16,32 \mu \mathrm{M}$ & $\begin{array}{l}\text { Clinical trial, } 11 \text { female } \\
\text { patients and } 7 \text { controls } \\
\text { aged } 18-65 \text { years }\end{array}$ & $\begin{array}{l}\beta \text {-sitosterol at } 4 \mu \mathrm{M} \text { causes decrease in the release of } \\
\text { TNF- } \alpha \text { and at } 4 \text { and } 16 \mu \mathrm{M} \text { causes decrease in the release } \\
\text { of IL-12 in the PBMCs of multiple sclerosis patients }\end{array}$ & 26 \\
\hline $\begin{array}{l}\text { Curcumin } \\
\text { (polymerized } \\
\text { nano-curcumin) }\end{array}$ & $\begin{array}{l}\text { Intraperitoneal } \\
\text { administration of } \\
\text { polymerized nano- } \\
\text { curcumin at } 12.5 \mathrm{mg} / \mathrm{kg}\end{array}$ & $\begin{array}{l}\text { Animal model of EAE, } \\
\text { Female Lewis rats }\end{array}$ & $\begin{array}{l}\text { Decreasing neurologic deficits, demyelination, } \\
\text { inflammation, } \\
\text { blood-brain barrier permeability, oxidative stress; } \\
\text { Improving remyelination } \\
\text { Increasing the precursor of cell marker }\end{array}$ & 27 \\
\hline $\begin{array}{l}\text { Lipia citriadora } \\
\text { (lemon verbena) }\end{array}$ & $\begin{array}{l}\text { Extract at } 600 \mathrm{mg} / \text { day } \\
\text { PLX capsules } \\
\text { containing } 10 \% \\
\text { verbascoside } \mathrm{w} / \mathrm{w} \\
\text { administered for } 28 \\
\text { days }\end{array}$ & $\begin{array}{l}\text { Clinical trial; Double- } \\
\text { blind, placebo- } \\
\text { controlled } \\
30 \text { patients }\end{array}$ & $\begin{array}{l}\text { Decreasing C-reactive protein, IFN- } \gamma \text { levels, IL-12 levels, } \\
\text { IL-4 and IL-10 levels }\end{array}$ & 28 \\
\hline Capparis ovata & $\begin{array}{l}\text { Butanol fraction of } \\
\text { hydroalcoholic extract }\end{array}$ & $\begin{array}{l}\text { In vitro study with } \mathrm{SH}- \\
\text { SY5Y cell line }\end{array}$ & $\begin{array}{l}\text { Inhibiting the expression of the genes below in cell lines: } \\
\text { TNF- } \alpha \text {, NF- } \kappa B 1 \text {; GFAP, CXCL10, PTPN11 }\end{array}$ & 29 \\
\hline $\begin{array}{l}\text { Pomegranate } \\
\text { peel } \\
\text { extract }\end{array}$ & $\begin{array}{l}\text { Ethanol extract, } \\
\text { intraperitoneal } \\
\text { administration at } 100 \\
\mathrm{mg} / \mathrm{kg} \text { for } 8 \text { days }\end{array}$ & $\begin{array}{l}\text { In vitro study with } \\
\text { female DA rat model } \\
\text { of } E A E\end{array}$ & $\begin{array}{l}\text { Inhibiting the production of IL-17 in the GALT cell line; } \\
\text { Decreasing the production of IL-17 in the activated T cell of } \\
\text { an animal model of EAE }\end{array}$ & 30 \\
\hline Ginkgo biloba & $\begin{array}{l}120 \mathrm{mg} / \text { day for } 8 \\
\text { weeks }\end{array}$ & $\begin{array}{l}\text { Open study, } 30 \text { patients; } \\
\text { Wechsler Memory Scale } \\
\text { Beck Depression } \\
\text { Inventory and the } \\
\text { MSIS-29 }\end{array}$ & $\begin{array}{l}\text { Improving the scores on Wechsler Memory Scale and } \\
\text { MSIS-29 }\end{array}$ & 31 \\
\hline
\end{tabular}


Table 1. Continued

\begin{tabular}{|c|c|c|c|c|}
\hline $\begin{array}{l}\text { The name of plant } \\
\text { or compound }\end{array}$ & Concentration & Study design and subjects & Properties & Reference \\
\hline $\begin{array}{l}\text { Boswellia } \\
\text { papyrifera }\end{array}$ & $\begin{array}{l}\text { Receiving two } \\
\text { Boswellia papyrifera } \\
\text { capsules ( } 300 \mathrm{~g}) \text { per } \\
\text { day for } 2 \text { months }\end{array}$ & $\begin{array}{l}\text { Randomized, double- } \\
\text { blind clinical trial with } \\
80 \text { patients using Brief } \\
\text { International Cognitive } \\
\text { Assessment for MS }\end{array}$ & $\begin{array}{l}\text { Improving spatial memory; Not influencing verbal memory } \\
\text { and information processing speed }\end{array}$ & 32 \\
\hline $\begin{array}{l}\text { Pterodon } \\
\text { emarginatus } \\
\text { seeds }\end{array}$ & $\begin{array}{l}\text { Oral use of essential } \\
\text { oil ( } 50 \text { and } 100 \mathrm{mg} / \mathrm{kg} \text { ) }\end{array}$ & Mouse model of EAE & $\begin{array}{l}\text { Decreasing neurologic deficits } \\
\text { Inhibiting immune response by Th1 cell, axonal } \\
\text { demyelination and neuronal death; Regulating Treg } \\
\text { response in vitro } \\
\text { Activating microglia and expressing iNOS }\end{array}$ & 34 \\
\hline
\end{tabular}

THC: Tetrahydrocannabinol, CBD: Cannabidiol, SIT: $\beta$-sitosterol, TNF: Tumor nuclear factor, IL: Interleukin, PBMC: Peripheral blood mononuclear cell, EAE: Experimental

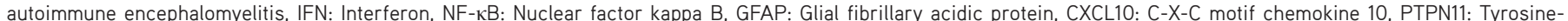

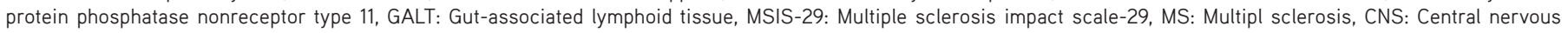
system, iNOS: Inducible nitric oxide synthase

than in healthy people. Due to the lack of strong evidence to support the effectiveness of the available treatments, the use of medicinal plants continues to increase in frequency. Despite the lack of controlled studies, there is a partial yet confirmed association between the dosage and the efficacy of medicinal plants. ${ }^{36}$

We conducted the current review to investigate the results of studies with animals and humans regarding the effects of medicinal plants and plant compounds on treatment of MS.

Most studies have been conducted with Cannabis sativa and its compounds. C. sativa has been used for several pharmaceutical purposes for 4000 years, but the structure and the properties of its compounds, such as cannabinoid, have been identified only in the last few years. To date, two cannabinoid receptors, CB1 and CB2, have been cloned. Endocannabinoids are metabolized by an amino acid called fatty acid amide hydrolase and monoglyceride lipase. ${ }^{37}$

The endocannabinoid system is currently the therapeutic target for treating many diseases, including MS. Clinical evidence confirms the therapeutic potential of cannabinoids to treat MS symptoms. ${ }^{25}$ Numerous studies have been conducted to investigate the effects of cannabinoids in MS treatment, suggesting that they may yield improvements in spasticity, muscle spasm, neuropathic pain, and urinary tract complications in at least some patients. These studies are not longitudinal, with treatments of over 10 to 15 weeks. ${ }^{22,38,39}$

It is estimated that over $80 \%$ of MS patients suffer from spasticity. Oral antispasmodics such as baclofen and benzodiazepines often fail to control these symptoms and therefore new, effective, and safe drugs are required. ${ }^{40,41}$ Nabiximols is a cannabinoid-based oral drug that is composed of tetrahydrocannabinol (THC) and cannabidiol (CBD) at a ratio of approximately 1:1 $(2.7 \mathrm{mg} \mathrm{THC}$ and $2.5 \mathrm{mg} C B D / 100 \mathrm{~mL}){ }^{42}$ Several randomized clinical trials have shown the efficacy of this drug in reducing limb spasticity and pain in MS patients. ${ }^{25,43-46}$

Studies showed that $\beta$-sitosterol and lemon verbena reduced the secretion of $\mathrm{IL}-12$ and TNF- $\alpha$ in the peripheral blood mononuclear cells of MS patients. ${ }^{26,28}$ Phytosterols and lemon verbena can affect the signaling pathways in tumor cells, including the stimulation of apoptotic pathways and the sphingomyelin cycle as well as the inhibition of prostaglandin release from macrophages in the culture medium. Therefore, a possible mechanism of these can be influencing certain signaling pathways that regulate the synthesis and release of cytokines. ${ }^{26,28}$

Based on preliminary research on cell cultures and animal models, pilot and clinical studies suggest that curcumin may be a therapeutic agent in several inflammatory diseases associated with Th17 cells such as MS, Alzheimer disease, Parkinson disease, inflammatory bowel disease, and rheumatoid arthritis. Curcumin, as an inhibitor of nuclear factor kappa B, is effective in preventing BBB breakdown caused by Th17 cells by influencing ZO-1 expression, inhibiting myosin light chain phosphorylation, and eliminating reactive oxygen species. ${ }^{47}$

Cognitive changes represent a major problem among MS patients that can simultaneously be more influential than the physical disabilities due to this disease. Ginkgo treatment for 
8 weeks caused a significant improvement according to the Wechsler Intelligence Test. ${ }^{31}$

Punica granatum peel extract exerts significant immune effects that lead to prevention or treatment of EAE or streptozotocininduced type 1 diabetes. This extract effectively inhibits the production of IL-17 in certain lymphatic tissues and also Th17 in the immune system. ${ }^{30}$

Cognitive impairments represent one of the most important disorders among MS patients, with a $43-70 \%$ prevalence rate. ${ }^{48}$ Boswellia papyrifera can significantly improve the spatial memory of MS patients. Two studies have separately attributed the improving effects of $B$. papyrifera and Crocus sativus $L$. to their antioxidant properties. ${ }^{32,33}$

\section{CONCLUSIONS}

Taken together, phytotherapy is a useful approach to decrease MS symptoms and leads to reduction of fatigue, pain, and stress in MS patients. However, physicians and neurologists are recommended to gain certain information about complementary and alternative therapies and to assess the patients' experiences by discussing this area with them.

\section{ACKNOWLEDGEMENT}

This study was funded by the Research and Technology Deputy of Shahrekord University of Medical Sciences.

Conflicts of Interest: No conflict of interest was declared by the authors.

\section{REFERENCES}

1. Franklin RJ. Why does remyelination fail in multiple sclerosis? Nat Rev Neurosci. 2002;3:705-714.

2. McQualter JL, Bernard CC. Multiple sclerosis: a battle between destruction and repair. J Neurochem 2007;100:295-306.

3. Olsen SA. A review of complementary and alternative medicine (CAM) by people with multiple sclerosis. Occup Ther Int. 2009;16:57-70.

4. Mirzai V, Saiadi AR, Heydarinasab M. Knowledge and attitude of Rafsanjan physicians about complementary and alternative medicine. Zahedan J Res Med Sci. 2011;13:20-24.

5. Goodin DS, Frohman EM, Garmany GP Jr, Halper J, Likosky WH, Lublin FD, Silberberg DH, Stuart WH, van den Noort S; Therapeutics and Technology Assessment Subcommittee of the American Academy of Neurology and the MS Council for Clinical Practice Guidelines. Disease modifying therapies in multiple sclerosis: report of the Therapeutics and Technology Assessment Subcommittee of the American Academy of Neurology and the MS Council for Clinical Practice Guidelines. Neurology. 2002;58:169-178.

6. Yadav V, Bever C Jr, Bowen J, Bowling A, Weinstock-Guttman B, Cameron M, Bourdette D, Gronseth GS, Narayanaswami P. Summary of evidence-based guideline: Complementary and alternative medicine in multiple sclerosis Report of the Guideline Development Subcommittee of the American Academy of Neurology. Neurology. 2014;82:1083-1092.

7. Rabiei Z, Rafieian-kopaei M, Heidarian E, Saghaei E, Mokhtari S. Effects of Zizyphus jujube extract on memory and learning impairment induced by bilateral electric lesions of the nucleus Basalis of Meynert in rat. Neurochem Res. 2014;39:353-360.

8. Rabiei Z, Mokhtari S, Asgharzade S, Gholami M, Rahnama S, Rafieiankopaei M. Inhibitory effect of Thymus vulgaris extract on memory impairment induced by scopolamine in rat. Asian Pac J Trop Biomed. 2015;5:845-851.

9. Rabiei Z, Rafieian-Kopaei M. Neuroprotective effect of pretreatment with Lavandula officinalis ethanolic extract on blood-brain barrier permeability in a rat stroke model. Asian Pac J Trop Med. 2014;7:421426.

10. Rabiei Z, Bigdeli MR, Rasoulian B, Ghassempour A, Mirzajani F. The neuroprotection effect of pretreatment with olive leaf extract on brain lipidomics in rat stroke model. Phytomedicine. 2012;19:940-946.

11. Rabiei Z, Gholami M, Rafieian-Kopaei M. Antidepressant effects of Mentha pulegium in mice. Bangladesh J Pharmacol. 2016;11:711-715.

12. Rabiei Z, Naderi S, Rafieian-Kopaei M. Study of antidepressant effects of grape seed oil in male mice using tail suspension and forced swim tests. Bangladesh J Pharmacol. 2017;12:397-402.

13. Rabiei Z, Lorigooini Z, Kopaei MR. Effects of hydroalcoholic extract of Borago officinalis on naloxone-precipitated withdrawal syndrome in morphine-dependent mice. Bangladesh J Pharmacol. 2016;11:824-829.

14. Giveon S, Liberman N, Klang S, Kahan E. A survey of primary care physicians' perceptions of their patients' use of complementary medicine. Complement Ther Med. 2003;11:254-260.

15. Hollenbach JA, Oksenberg JR. The immunogenetics of multiple sclerosis: a comprehensive review. J Autoimmun. 2015;64:13-25.

16. Conti P, Kempuraj D. Important role of mast cells in multiple sclerosis. Mult Scler Relat Disord. 2016;5:77-80.

17. Zrzavy T, Hametner S, Wimmer I, Butovsky O, Weiner HL, Lassmann H. Loss of 'homeostatic' microglia and patterns of their activation in active multiple sclerosis. Brain. 2017;140:1900-1913.

18. Raphael I, Nalawade S, Eagar TN, Forsthuber TG. T cell subsets and their signature cytokines in autoimmune and inflammatory diseases. Cytokine. 2015;74:5-17.

19. Zhu J, Jankovic D, Oler AJ, Wei G, Sharma S, Hu G. The transcription factor $\mathrm{T}$-bet is induced by multiple pathways and prevents an endogenous Th2 cell program during Th1 cell responses. Immunity. 2012;37:660-673.

20. Jadidi-Niaragh F, Mirshafiey A. Th17 cell, the new player of neuroinflammatory process in multiple sclerosis. Scand J Immunol. 2011;74:1-13.

21. Zajicek JP, Hobart JC, Slade A, Barnes D, Mattison PG; MUSEC Research Group. Multiple Sclerosis and Extract of Cannabis: results of the MUSEC trial. J Neurol Neurosurg Psychiatry. 2012;83:1125-1132.

22. Brady CM, DasGupta R, Dalton C, Wiseman OJ, Berkley KJ, Fowler CJ. An open-label pilot study of cannabis-based extracts for bladder dysfunction in advanced multiple sclerosis. Mult Scler J. 2004;10:425433.

23. Buccellato E, Carretta D, Utan A, Cavina C, Speroni E, Grassi G, Candeletti S, Romualdi P. Acute and chronic cannabinoid extracts administration affects motor function in a CREAE model of multiple sclerosis. J Ethnopharmacol. 2011;133:1033-1038.

24. Vaney C, Heinzel-Gutenbrunner M, Jobin P, Tschopp F, Gattlen B, Hagen U, Schnelle M, Reif M. Efficacy, safety and tolerability of an orally administered cannabis extract in the treatment of spasticity in patients 
with multiple sclerosis: a randomized, double-blind, placebo-controlled, crossover study. Mult Scler. 2004;10:417-424.

25. Wade DT, Makela P, Robson P, House H, Bateman C. Do cannabis-based medicinal extracts have general or specific effects on symptoms in multiple sclerosis? A double-blind, randomized, placebo-controlled study on 160 patients. Mult Scler. 2004;10:434-441.

26. Desai F, Ramanathan M, Fink CS, Wilding GE, Weinstock-Guttman B, Awad $\mathrm{AB}$. Comparison of the immunomodulatory effects of the plant sterol beta-sitosterol to simvastatin in peripheral blood cells from multiple sclerosis patients. Int J Immunopharmacol. 2009;9:153-157.

27. Mohajeri M, Sadeghizadeh M, Najafi F, Javan M. Polymerized nanocurcumin attenuates neurological symptoms in EAE model of multiple sclerosis through down regulation of inflammatory and oxidative processes and enhancing neuroprotection and myelin repair. Neuropharmacology. 2015;99:156:167.

28. Mauriz E, Vallejo D, Tunon MJ, Rodriguez-Lopez JM, RodriguezPerez R, Sanz-Gomez J, García-Fernández Mdel C. Effects of dietary supplementation with lemon verbena extracts on serum inflammatory markers of multiple sclerosis patients. Nutr Hosp. 2015;31:764-771.

29. Sen A, Topcu G, Ozgun O, Kolak U, Hacibekiroglu I, Celik G, Arslan S. Anti-neuroinflammatory effect of butanolic subextract of Capparis ovata water extract used as an alternative andcomplementary treatment for multiple sclerosis. J Neuroimmunol. 2014;275:172-173.

30. Stojanovic I, Savikin K, Dedovic N, Zivkovic J, Saksida T, Momcilovic M, Koprivica I, Vujicic M, Stanisavljevic S, Miljkovic D, Menkovic N. Pomegranate peel extract ameliorates autoimmunity in animal models of multiple sclerosis and type 1 diabetes. J Funct Foods. 2017;35:522530.

31. Noroozian M, Mohebbi-Rasa S, Tasviechi A, Sahraian M, Karamghadiri N, Akhondzadeh S. Ginkgo biloba for Improvement of Memory and Quality of Life in Multiple Sclerosis: an Open Trial. J Med Plant Res. 2011;3:33-49.

32. Sedighi B, Pardakhty A, Kamali H, Shafiee K, Hasani BN. Effect of Boswellia papyrifera on cognitive impairment in multiple sclerosis. Iranian J Neurol. 2014;13:149.

33. Ghazavi A, Mosayebi G, Salehi H, Abtahi H. Effect of ethanol extract of saffron (Crocus sativus L.) on the inhibition of experimental autoimmune encephalomyelitis in C57bl/6 mice. PJBS. 2009;12:690-695.

34. Alberti TB, Marcon R, Bicca MA, Raposo NR, Calixto JB, Dutra RC. Essential oil from Pterodon emarginatus seeds ameliorates experimental autoimmune encephalomyelitisby modulating Th1/Treg cell balance. J Ethnopharmacol. 2014;155:485-494.

35. Martín R, Carvalho-Tavares J, Hernández M, Arnes M, Ruiz-Gutierrez $\checkmark$, Nieto ML. Beneficial actions of oleanolic acid in an experimental model of multiple sclerosis: a potential therapeutic role. Biochemical Pharmacology. 2010;79:198-208.

36. Claflin SB, van der Mei IA, Taylor BV. Complementary and alternative treatments of multiple sclerosis: a review of the evidence from 2001 to 2016. J Neurol Neurosurg Psychiatry. 2017;1:1-8.

37. Matsuda LA, Lolait SJ, Brownstein MJ, Young AC, Bonner TI. Structure of a cannabinoid receptor and functional expression of the cloned cDNA. Nature. 1990;346:561-564.

38. Lakhan SE, Rowland M. Whole plant cannabis extracts in the treatment of spasticity in multiple sclerosis: a systematic review. BMC Neurol. 2009;9:59.

39. Brady CM, DasGupta R, Wiseman OJ, Dalton CM, Berkley KJ, Fowler CJ. The effect of cannabis based medicinal extract on lower urinary tract dysfunction in advanced multiple sclerosis: Preliminary results. J Neurol Neurosurg Psychiatry. 2002;72:139.

40. Beard S, Hunn A, Wight J. Treatments for spasticity and pain in multiple sclerosis: a systematic review. Health Technol Assess. 2003:7.

41. Shakespeare DT, Young CA, Boggild M. Anti-spasticity agents for multiple sclerosis. Cochrane Database Syst Rev. 2000:CD001332.

42. Syed YY, McKeage K, Scott LJ. Delta-9-tetrahydrocannabinol/ cannabidiol (Sativex ${ }^{\circledast}$ ): a review of its use in patients with moderate to severe spasticity due to multiple sclerosis. Drugs. 2014;74:563-578.

43. Collin C, Davies P, Mutiboko I, Ratcliffe S. Randomized controlled trial of cannabis-based medicine in spasticity caused by multiple sclerosis. Eur J Neurol. 2007;14:290-296.

44. Collin C, Ehler E, Waberzinek G, Alsindi Z, Davies P, Powell K, Notcutt W, O'Leary C, Ratcliffe S, Nováková I, Zapletalova O, Piková J, Ambler Z. A double-blind, randomized, placebo-controlled, parallel-group study of Sativex, in subjects with symptoms of spasticity due to multiple sclerosis. Neurol Res. 2010;32:451-459.

45. Novotna A, Mares J, Ratcliffe S, Novakova I, Vachova M, Zapletalova $O$, et al. A randomized, double-blind, placebo-controlled, parallel-group, enriched-designstudy of nabiximols (Sativex ${ }^{\circledR}$ ), as add-on therapy, in subjects with refractory spasticity caused by multiple sclerosis. Eur $\mathrm{J}$ Neurol. 2011;18:1122-1131.

46. Notcutt W, Langford R, Davies P, Ratcliffe S, Potts R. A placebocontrolled, parallel-group, randomized withdrawal study of subjects with symptoms of spasticity due to multiple sclerosis who are receiving long-term Sativex ${ }^{\circledR}$ (nabiximols). Mult Scler J. 2012;18:219-222.

47. Xie L, Li XK, Takahara S. Curcumin has brightprospects for the treatment of multiple sclerosis. Int J Immunopharmacol. 2011;11:323-330.

48. Bobholz JA, Rao SM. Cognitive dysfunction in multiple sclerosis: a review of recent developments. Curr Opin Neurol. 2003;16:283-288. 